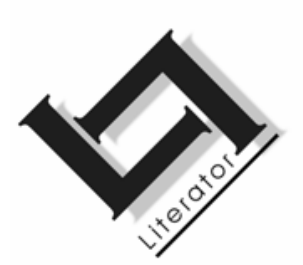

\title{
Alan Paton's unpublished fiction (1922- 1934): an initial appraisal
}

David Levey

Department of English Studies

UNISA

PRETORIA

E-mail: leveydnr@unisa.ac.za

editsa@gmail.com

\begin{abstract}
Alan Paton's unpublished fiction (1922-1934): an initial appraisal
\end{abstract}

This article considers selected issues in the early fiction of Alan Paton, which is in manuscript form: three novels or parts of novels namely, "Ship of Truth" (1922-1923), "Brother Death" (1930), "John Henry Dane" (1934b), the novel/novella "Secret for seven" (1934d), and the short stories "Little Barbee", (1928?) and "Calvin Doone" (1930a). Attention is given to the first novel. A summary of the findings follows: even though Paton's longer unpublished fiction is religiously earnest and at times rhetorically effective, it is simplistic and tends to perpetuate the white, English-speaking patriarchal hegemony of Natal, rather than offer any sustained critique of it. These works are set against the background of the Natal Midlands in the 1920s and 1930s. The shorter fiction is slightly different in nature.

\section{Opsomming}

Alan Paton se ongepubliseerde fiksie (1922-1934): 'n eerste evaluering

Hierdie artikel handel oor geselekteerde onderwerpe in die vroeëre fiksie van Alan Paton, wat nog steeds in manuskripvorm is: drie romans of dele van romans, naamlik "Ship of Truth" (1922-1923), "Brother Death" (1930a), "John Henry Dane" (1934b), 'n roman of kort roman, "Secret for seven" (1934d), en die kortverhale "Little Barbee" (1928?) en "Calvin Doone" (1930b). Daar word op die eerste roman gefokus. Paton se langer ongepubliseerde fiksie is toegewyd en godsdienstig, 
en soms retories suksesvol, maar dit is ook simplisties en geneig om die wit, Engelssprekende hegemonie in Natal gedurende die twintiger- en dertigerjare voort te sit, eerder as om dit deeglik te bevraagteken. Hierdie werke speel af teen die agtergrond van die Natalse Middellande in die twintiger- en dertigerjare. Die aard van die korter fiksie is ietwat anders.

\section{Introduction}

The object of this article is twofold: firstly to record some of the findings of a recent doctoral investigation (Levey, 2007) into certain manuscripts in the Alan Paton Centre and Struggle Archives, University of KwaZulu-Natal, Pietermaritzburg, which place the young Alan Paton in a slightly different light from that hitherto cast on him, and secondly, to introduce one of these works, Paton's first novel: Ship of truth (approximately 1922-1923). Certain trends which emerge are identified, though a complete survey cannot be offered. Brief parallels are also adduced with the other early fiction in the hope that these intriguing works will be studied more widely. Appropriate theory is adduced in the aforesaid thesis.

It would seem logical for any study of Paton to begin with some of his earliest writings (the novels Ship of truth, 1922-1923?, Brother Death, c. 1930a, John Henry Dane, 1934b, the novel/novella Secret for seven, 1934d, the short stories Little Barbee, 1928? and Calvin Doone, 1930b) - not all these titles are Paton's own - yet with few exceptions most work on him has dealt with his familiar published oeuvre. 1 However, these texts, by narrating the "smaller stories" of which De Kock speaks (1996:87), make a valuable contribution to the larger picture of the various South African identities and literatures which has been attracting scholarly interest for a number of years now. The reader is referred to the thesis of Levey (2007) itself for a more detailed consideration of the mature Paton's feelings regarding his early work (mostly dismissive) and of the attitudes he held in his youth.

To summarise, though Paton's longer unpublished fiction is religiously earnest and at times rhetorically effective, it is simplistic and tends to perpetuate the white, English speaking patriarchal hege-

1 His other important unpublished early work, such as the several drafts of his play Louis Botha (1932-1933), his lecture on God in modern thought (1934a) or his unfinished manuscript Religion, freedom and man (1934c), is also worthy of studying in its own right. 
mony of Natal (particularly the Midlands) in the 1920s and 1930s, where these works are set, rather than offer any sustained critique of it.

In the thesis of Levey (2007) an eclectic approach was consciously adopted which was appropriate to these particular writings by Paton: firstly some of the basic techniques of textual analysis and discourse analysis (the latter becoming an increasingly important means of discussing Paton; Martinez Lirola, 2006); secondly narrative theory relating to focalisation and inferred authorship; and thirdly an avowedly religious hermeneutical viewpoint. Focalisation proved a useful tool in discussing the underlying norms of the texts, since it became clear that the narrator largely conveys Paton's own values and is often not very distinct from him, particularly in Ship of truth (Rimmon-Kenan, 2002:82-83; cf. Foley, 2005:84). In this context Paton represents my own construct, the author whose existence is inferred on the basis of clues in the texts and in what is known about Paton generally, for example from his biography (Alexander, 1994) and autobiographies (Paton, 1980 and 1988). Because the term "inferred author" (Abbott, 2002:77-78) prioritises the activity of the reader it was preferred to that of the "implied author", which suggests that the text itself implies who the author is. Valuable in discussing the ideology of early twentieth-century white English speaking Natal Midlands society were the studies by Morrell (2001) and Thompson (1999). Levey (2007) and the present article adopt their social constructionist arguments.

In terms of an explicitly religious critique of Paton, one may perceive not only deep commitment and some skill, but also an earnest and sometimes forced "writing in" of Christian ideas. There are unfortunately also a number of major failings: a "writing out" of the role of women, and even more so of the presence of black people, and not much apparent awareness of the major events outside the Natal Midlands (even within the South African milieu). ${ }^{2}$ As Paton himself acknowledges, when he entered university in March 1919, he knew almost nothing of the political events of the time (Paton, 1980:55).

2 Such events include the Natives Land Act of 1913, the first World War (mentioned occasionally), the Rand Revolt (1922) and the Great Depression of 1929-1931 (Davenport \& Saunders, 2004:271-272, 317-323). The Bhambatha Rebellion of 1906 (Davenport \& Saunders, 2004:242) does feature in John Henry Dane, but only to provide a melodramatic backdrop drawing on the trope of the "swart gevaar": it is not perceived as a key incident in the relentless march of British colonialism (Lambert, 2006:17). 
Foley has pointed out that Paton was not a liberal all his life (Foley, 1998:64), ${ }^{3}$ and the novels from this phase can be described as, at best, "pre-liberal" in outlook. ${ }^{4}$ Paton's own self-preoccupation with religious doubt in 1923, occasioned by the behaviourism of J.B. Watson, and the severe enteric fever which he contracted in 1934, might well have distracted him from social and political issues. But they did not stop him writing.

In the following sections a few selected major characteristics of Paton's early fiction are discussed.

\section{Aspects of identity in the early fiction}

As De Kock $(2001: 271 ; 2004: 8)$ has noted, multiple constructions of identity exist in this country. In most of his earliest fiction Paton is only vaguely aware of differing individual identities, and except in his slightly later novel Brother Death (1930a), is nowhere near comprehending any national consciousness. Hence the lack of a sense of national identity, and the correspondingly limited personal identities of his characters, are themselves telling, especially if one considers the development of such identities in Cry, the beloved country and Too late the phalarope.

In Paton's early fiction the representation of identity remains on the surface. Men are, on the whole, well-to-do farmers, though occasionally a male figure differs from the norm, slightly interrogating it; women are objects of simplistic gender stereotyping; the communities are limited mostly to a few middle or upper-class English speakers; significantly, members of the black populace are almost entirely absent, except as depersonalised individuals or remotelyviewed groups.

3 Paton's liberalism seems to have fluctuated and would furnish interesting material for further research. Even in 1951 he could write to Sarah Gertrude Millin congratulating her on the second edition of The people of South Africa, calling it her "greatest" work: peculiar accolades in the light of her outright racism (cf. Coetzee, 1988:150, 160-161).

4 Cornwell (1992:79) comments that the liberal opponent of racial discrimination responds with anger and compassion, guilt and equivocation. At most the young Paton experiences the last of these reactions. One could also situate the early Paton in general within the ranks of the "social Christians" who were disturbed by the living conditions of blacks and wished to ameliorate them (Elphick, 1997:347-369). 
Since these works are little known I summarise them briefly, concentrating on the earliest novel, Ship of Truth (hereafter ST) because of its interest for Paton's work, drawing occasional comparisons with the other works of fiction. It narrates the story of a group of English speaking families in rural Natal, dealing largely with the friendship between an older farmer, Jenkinson, and the younger protagonist, Michael Shearer. The quasi-allegorical significance of the title is not developed and the novel is unfinished. The second Book (of three) has disappeared, but one can reasonably easily deduce its tenor.

Paton's second novel, Brother Death (BD), in many ways less successfully repeats aspects of ST; the third, John Henry Dane (JHD), and the fourth, Secret for seven (SFS), 5 are likewise set in rural Natal. BD, an unwieldy work of 716 pages, a number of which have been emended, crossed out or excised altogether, in essence concerns a feud between two brothers-in-law, Anthony Cromwell and Richard Jarvis, which is resolved when the latter, a forebear of the later James Jarvis, develops throat cancer and is converted to Christianity. The novel is set in Ixopo, called Atherton in the text. God is often conceived of by the narrator and by two key figures, the elderly, drunken doctor Macnab and the Anglican priest Montague Legh, as rather like Francis Thompson's Hound of heaven (specifically referred to on several occasions, e.g. BD, p. 229-232) to the present reader, relentless and threatening. Jarvis, whose conversion results from Legh's insistence upon right relationships with God and one's fellow human beings, is eventually claimed by his "brother", Death, who seems to act as a more merciful surrogate for God. Hence the deity is actually absent from the scene at the novel's end. One of Paton's signature techniques, repetition, is quite effectively used at the beginning and end of this work (BD, p. 1, 715). It concerns the austere Cromwell staring into the "white darkness" of the mists which, as in the real Ixopo, often veil the countryside, but also connote Cromwell's lack of vision and inability to relax into a human understanding of most of his fellows. I would suggest that the oxymoron also conveys Paton's inability fully to examine the complexities of identity.

$5 \quad$ Though Alexander (1994:119) and Wittenberg $(2004: 185 ; 2005: 16)$ identify it as a short story, a plot sketch shows that the manuscript was planned to cover three periods of Margaret Mbata's life, and where the manuscript breaks off on p. 8, the narrative is only part of the way through the first, "Childhood". Hence I suspect the work was intended to be a novella or novel. 
JHD concerns an introspective narrator who is very different from his macho father and brothers, but nevertheless, according to a sketch of the plot, was intended to end up as a farmer. John is born into the panic of the 1906 "Rebellion" which negatively affects the attitudes of white people towards black people. Though Paton was perhaps intending to critique the hard masculine hegemony in Natal by creating a sensitive and imaginative narrator, the novel does not explore this possibility fully. Interestingly, God makes no appearance at all. But in SFS, where a black-skinned daughter is born to Charles Draper, a soldier of upper-class origins who has married a lowerclass English speaking woman of dubious descent, Christians and their God come in for strong critique. Draper's parents insist that it be said that the child has died, and she is given to a convent of Anglican nuns, a "place of peace", dominated in every corner by crucifixes and images of Madonna and child. The sisters connive at the falsehood that she is black by, among other things, requiring her always to wear a kerchief to hide her hair. However, the secret is difficult to keep because "Margaret Mbata" can speak English very well, unlike the other black children, and keeps forgetting her head covering. Regrettably the narrative ends at this point, but I consider that Paton has launched on an unusual criticism of the racism and hypocrisy of institutionalised religion and certain white Christians.

Most of these novels, whether in plot, religious sophistication, political and historical awareness or social conscience, evidence very little of the mature Paton. Thus, the initial hypothesis that these works constituted the seedbed of the writer's published novels was largely disproven, though links do exist in Christian themes, names of characters, certain narrative and stylistic techniques, the Natal environment and the like.

Two intriguing short stories, Little Barbee (1928?)6 and Calvin Doone (1934; in the same manuscript as BD) complete the corpus of what appears to be Paton's surviving unpublished fiction. They are set in the United States: the first (Little Barbee) is a tale of the Wild West with a twist, where the "terrible Barbee brothers" are shown to have a soft spot for their mother. While Little Barbee is, ironically, a huge cowboy his brother is a small and dapper lawyer; yet, it turns out, a man even quicker at the draw than his brother. The second story (Calvin Doone) concerns two white men, one in the United States and one in Africa, who are, or who become,

6 Dated thus by Paton himself in pen; the manuscript itself is in pencil. 
insane. In these two narratives, to my mind, Paton is attempting to break away from the stereotypical white Natalians and male identities of his other early fiction. In Calvin Doone he also relies on exoticising Africa, in the trope of the Mountains of the Moon (cf. Wittenberg, 2004:80-87).

\section{Stereotypes and stock characters}

First, the identities of individuals are considered. Relevant stereotypes in ST include the strong, selfless Jenkinson (to some extent paralleling the figure of Cromwell in BD) and the Anglican ministers Esmond (a weak and ineffectual figure) and Deasland (who embodies practically all the Christian virtues). In BD two further priests, the Anglican Legh and the Catholic Hugo, perform much the same roles. The women mostly fill the parts of home-makers and the like, while non-English speakers, apart from the newly-arrived Afrikaans doctor Jan Krige in BD, largely exist on the periphery. Black characters are evident only as shadowy servants, accorded no names or English ones at most, effectively banished to the margins of alterity. The attitudes of the narrator and all the characters towards them are at best remote and patronising.

Such stereotypes are well summed up in the desire of Naomi, one of Michael Shearer's sisters, to become a nurse: “That's a great profession,' said Jenkinson, warming to one of his favourite themes. 'Nursing \& motherhood. And for a man, the ministry \& teaching \& doctoring.'" (ST, p. 66) It hardly needs remarking that these professions are key signifiers of male and female identity in this novel, especially when Jenkinson, a normative character often approved of by the narrator, thus refers to them.

In particular, identity is bound up with class consciousness (not least the school one attends, emphasised in ST and JHD) and physical prowess. In a scene from ST, Michael Shearer reflects: "he did not speak to Tom or Richard [Westacres; the wealthiest family in the district], who were St. George's boys \& rather superior" (ST, p. 14). His sense of superiority to a ne'er-do-well, Hartley Ussher, as with his feeling of inferiority to the Westacres', again evidences an acute awareness of class, with the Shearers being placed squarely in the middle stratum (ST, p. 22). As the narrator records, "the comparative poverty of Politique [the Shearers' farm] had filled [Michael] with a desire to grow rich \& well-known, so that he could move in the best circles of the Kaffirlands without shame or embarrassment" (ST, p. 25). Therefore, not only an awareness of the identity into which 
Michael is socialised, but a desire to transcend it, is focalised through his eyes. ${ }^{7}$

Similarly, arrogance is intended to be seen as one of Dorothy Westacres's defining characteristics. Her physical features, such as her fair skin, remind one inescapably of her Englishness, but her most important attribute is her "erect stately carriage" (ST, p. 222). Paton's dwelling on this feature is monotonous, but the point is its association with the way she rules "unquestioning \& unquestioned". Similarly her mother does not quite approve of Jenkinson himself, but admits: "After all, Jenkinson's father-in-law was General BruceCarrington of Springflats" (ST, p. 80). ${ }^{8}$

In ST the "Duchess" (Mrs. Westacres) is said to rule over both her homestead and her husband, the "Duke". He, in language significant for its explicit reference to a wealthy English pastoral setting and certainly an allusion to Housman, ${ }^{9}$ whom one might term the poet laureate of such an environment and who consciously harks back to the past, is said to be "Richard Westacres, gentleman farmer of Shropshire, England" (ST, p. 70). However, owing to the negative portrayal of the Westacres' in the novel, one may argue that the allusion is not necessarily intended by Paton to be complimentary. ${ }^{10}$

This impression is reinforced by a scolding which Dorothy receives for being unladylike: coming up the steps two at a time (ST, p. 70) while visitors from the upper echelons of society, such as the local doctor, are present during a tennis party. Dr. Trollip's response to her is unashamedly masculine: that she is beautiful and that "the sight of all these youngsters gives me a queer pain somewhere. In

7 Morrell (2001:passim, e.g. 13-16) shows how keenly conscious the Natal settlers were of class. James Jarvis and Mainwaring (in Ah, but your land is beautiful [Paton, 1981:9-10]) are in this respect the lineal descendants of the Westacres'.

8 One is reminded of the marked British militarism in Natal (Morrell, 2001:139), and its being in many respects still a settler colony, by the heroic status accorded to senior officers in Paton's early work, who include General ScottMassingham in BD (p. 566), Colonel White and Major Dane in JHD (p. 1) and Major Massingham in SFS (p. 1).

9 In numerous places Paton acknowledges the strong influence of Housman (e.g. Paton, 1923:2 and 1980:63-64). A Shropshire lad (1896) is set in a strongly nostalgic and upper-class milieu (Housman Society, 2007; Brass, 2001:49).

10 The Carltons in BD fulfil a practically identical role except that their daughter, Sheila, is figured as a much more malevolent, even demonic, character. 
the heart, popular saying would have it. But it's not in the heart, of course. Where is it?" (ST, p. 71.) Dorothy suggests the appendix (ST, p. 72). The doctor complains, though not very convincingly, that she has ruined "a very agreeable train of thought". It is evident that Dorothy's liveliness is meant to counterpoint the Westacres's snobbishness, of which the narrator clearly does not approve, as with the Carltons in BD; it is equally obvious that the doctor finds her physically attractive, though he expresses this response euphemistically (ST, p. 72).

Second, matters of national identity are represented in a later speech by Trollip's son, Victor (ST, p. 271). Though his words are more rhetorical than heartfelt, they do reflect the tension in Natal between supporters of Union and its opponents; between the "liberal" Cape and narrow-minded Natal; and between the "overseas Englishman" and the "noble" - not the typical - South African embodied in Michael. Michael is portrayed, in the only words uttered by Victor awarded the accolade of "sincere", as idealistic but perhaps more able to contribute to future South African unity than the displaced Englishman and the Afrikaner, characters whom Victor contemptuously dismisses. This constitutes one of the infrequent situations in his early narratives where Paton exhibits any awareness of a larger identity than the "Midlandian". The other main instance occurs in BD, when Esther Jarvis marries Jan Krige. Jarvis, who had been vehemently opposed to any "Dutchman" marrying into his family, considers that the children of the marriage would nonetheless be true South Africans, with none of the prejudice that had afflicted their grandfathers. Secession would mean nothing to them but, he hopes, they will "always look upon England as a great country, the place of their mother's ancestors, a nation of whose record any man might be proud" (BD, p. 642). With pride Jarvis watches the couple, "children of the soil". He thinks

Both of them had had damned good educations; they didn't wear old hats, $\&$ chew straws. ... they were children of the soil, for all that; it showed in their ruddy cheeks, \& the straight way they held themselves (BD, p. 643).

The repetition emphasises Jarvis's ideology regarding educated people of the soil. Hence a more complex but still stereotyped notion of true identity is emerging here: (white) South African, rooted in the ground, educated, physically fit, yet also much influenced by Englishness. Other inhabitants of the country do not count. Paton might almost be describing himself, while certainly the canvas is being 
prepared for the portrait of the later Jarvis in Cry, the beloved country (Paton, 1948).

\section{An ambiguous pastoral environment11}

Further stereotypes, this time associating the identity of the characters with their surroundings, are relied upon when frogs, trees (especially wind in the trees) and birds, particularly doves, domesticate the environment and often comment on a character's state of mind. Motifs are present which recur throughout much of Paton's earliest fiction: for instance, in a Romantic sense of the person's oneness with the natural environment, which is at once vast and parochial/local (an English tumbling brook, ST, p. 10; English-looking haystacks, ST, p. 282). ${ }^{12}$ The source of identity as far as the characters are concerned is almost always English, not South African, and pastoral in nature.

Characters are acutely aware of the passing of time, because they live within a farming environment. Hence, for instance, an interlude opens with a seasonal shift from spring to summer (ST, p. 64). The few specific details do not detract from the sense of timelessness, of pastoral tranquillity, engendered by this interlude. Yet the ending, claiming that love, fear and sorrow have no part in this community and that "nothing happens to children", is patently false, since all these emotions are experienced by inhabitants and a young person has recently been killed in a plane crash. Time itself is consequently ambiguous, for, though it creates continuity and stability, it also brings change. This change is, generally speaking, disliked by most

11 Coetzee (1988:4-7, 64-66, 129) and Van Wyk Smith (2001:23) have both commented on the ambiguity of the pastoral (for instance, it is simultaneously Edenic and demonic).

12 As in Cry, the beloved country, the survey of the surrounding landscape from a position of elevation (Wittenberg, 2004:179-180) is in ST later accorded a more negative aspect. To my mind in Paton's earlier novels and in Cry the landscape indeed constitutes an important feature of his characters' sense of identity: the wealthy farmers occupy precisely such elevated territories, and the name "High Place" (used in four works) is especially significant for Paton: it is applied to the farm of the snobbish Carltons in BD, is found in its Zulu form "Emoyeni" in SFS (Wittenberg, 2004:185; 2005:16), in which form it is also a proposed name for the Westacres' property in ST (p. $73 \mathrm{ff}$.), and of course, denominates James Jarvis's farm. Since in Biblical terms a high place is a pagan shrine (Deut. 12:2; 1 Kings 12-14), one wonders if Paton is not implying that such farmers have made an idol of their wealth and power. They enjoy the colonisers' "commanding view" (Spurr, 1993:15) over both the landscape and its dispossessed inhabitants. 
characters and the narrator himself. In $\mathrm{BD}$, mirroring the community's and almost certainly Paton's resistance to it, it is observed that Change stalks down the main street (BD, p. 426).

The pastoral environment is likewise double-sided. While it is idealised on the whole, Paton does sound a darker note. He quite often employs the metaphor of a demon, as in a vignette disturbing for its violence (discussed further below), not only drawing attention to the darker aspects of human nature but also reminiscent of the tempter in the Garden of Eden.

In one scene, where the parson, Esmond, is asked to intervene in a matter of a drunkard son, which he is most reluctant to do, Jenkinson suggests that he (Jenkinson) will speak to the boy if he sees him first. Esmond agrees gratefully, admitting that he is "singularly lacking in the wisdom of the serpent" (ST, p. 53). Jenkinson's heart warms to "the ... shepherd of unwilling sheep". The images of the serpent and the sheep rather obviously reinforce the explicitly Edenic quality of the setting, a trope taken up frequently by Paton.

\section{Religion and other key signifiers of identity}

Unfortunately Paton's deep Christian commitment, apart from SFS, usually emerges in sentimental and superficial religiosity, with characters such as the manly missionary Deasland (and Legh and Hugo in BD) being consistent and zealous, but also, ultimately, exhibiting paternalist attitudes. In one scene, after a minor family spat, at bedtime Michael kneels down and repents before God "as he could not have done before his family. A better scholar, a better son, a better brother. He would be that tomorrow" (ST, p. 24). This is fairly typical of the representation of Christianity in the early fiction. Another example is the starchy conformity of the Anglican village church, where the Westacres' relate only to their social peers (ST, p. 27). Both Anglicans and Catholics maintain two racially distinct parishes (cf. BD, p. 319): the practice does not appear to trouble Paton.

In ST Michael's hero, Jenkinson, a believing Christian, spends much time and money on assisting other people, but neglects his wife, eventually conducting an affair with her sister. Undertaking with some misgivings to solve the family problem which Esmond cannot, Jenkinson first of all speaks to Gough, the barman, who appears cynical and unmoved. But shortly afterwards, on coming across the youngster in question, Jenkinson finds that Gough has already advised him to cease his drinking. This kind of improbable occurrence is not uncommon in Paton's early attempts at plotting. The sequence 
ends with the comment that Jenkinson "had a great need of faith" (ST, p. 58). This remark certainly captures Jenkinson's consciousness of a transcendent power which has solved the current issue and will be needed in the future. Yet to the present reader this power possesses the characteristics of a deus ex machina, arranging fortuitous meetings, dramatic changes of heart and benevolent natural surroundings.

Many key signifiers of identity are embodied in the person of Deasland (ST, p. 35), principal of the St. Luke's Training School: "doctor, teacher, \& parson all in one, \& an old blue on top of it; a man who might have played for England, but chose instead to educate the heathen in the reserves - a man who might have lent his strength to the [cricket] team, but was always - selfishly, some said - too busy up at St. Luke's" (ST, p. 35; see also p. 38, which associates the notions that he "fortunately was a gentleman" and "could handle a bat like an expert"). The explicit and emphasised norms of identity here are those of the muscular Christian (Mangan, 1981; 1990)13 whom Paton admires throughout his career as a writer. In contrast are the mundane values of some members of the community, who deem cricket as more important than the education of the heathen: a view which, I would argue, attracts the strong criticism of the narrator. Michael, influenced by Deasland, ultimately decides to become a teacher at St Luke's, but it is implied that even he is ambivalent about converting black people (ST, p. 276). His ambiguity leads me to the issue of the extremely significant undercurrents in these works.

\section{Dark underbelly; improbable plots}

Ironically, while Paton often sketches plot lines and characters, cohesive and convincing plots do not result. In BD he does so several times, demonstrating that he was finding it difficult to control the material. It certainly appears that on one level he was consciously attempting to express his Christian beliefs, which often tend towards the moralistic and patronising, but if one reads against the grain another, certainly unintended, meaning emerges. For instance, in an episode which Alexander (1994:72-73) rightly terms "powerful", during which a young farmer, Dirk Sotheran, gains the upper hand by sjambokking his father who runs a brothel, or allows his daught-

13 Van der Veer (2006:535) calls this, not without reason, an imperial Christianity and identifies its site with that of the public school and the novel, according precisely with Paton's evoking of this concept. 
ers to run one, the excessive violence and cruelty in Dirk are prominent. They call into question his seeming morality and protectiveness towards his younger sister (ST, p. 41-48). His ruthless exercise of power and the images of bestiality reinforce the general atmosphere. Paton is here clearly straining towards a representation of Dirk's identity as more complex than that of the run-of-the-mill rural person, in which the writer succeeds in hinting at the depths of the unconscious, but achieves a most ambiguous result. In JHD the narrator suffers from the physically brutal actions of two of his brothers, with similar effect.

Another example is to be found in the various strong feelings experienced by Jenkinson shortly before his sexual encounter with his wife's sister, Ruth, who is staying with the Jenkinsons: jealousy, loneliness, desire. These emotions are, importantly, largely damped down by Jenkinson resorting to clichés strongly associated with English culture, as in his frequent quoting of Masefield's verse and the tired exhortation (used often by Michael) to "play the game". Paton is showing the reader certain darker aspects of Jenkinson which Jenkinson obviously finds it difficult to acknowledge, immured in an English identity as he is. There appears to be an implicit critique of "Englishness" here which is not, however, taken much further, although certainly the author seems consciously to avoid too simplistic a representation of human identity. At the same time there is something of a fascination with sexuality which may be unconscious on Paton's part, though he does allow characters such as Jenkinson and Trollip to be aware of the attractiveness of certain women. Likewise, Sheila Carlton in BD is explicitly figured as a temptress who not only drives one young man to suicide, but is also disconcertingly alluring to Krige (e.g. BD, p. 176-178).

Paton treats the actual physical consummation of Jenkinson's affair with Ruth exceedingly obliquely. It is as if the conventions of the realistic novel (found in one of his literary models, Thomas Hardy; cf. ST, p. 16, verso) within which he is writing oblige him to admit flaws in his characters, but he is reluctant to do so.14 He overcomes this difficulty by using the rather frequent technique of a sudden turn in the plot.

14 In a remarkable unnumbered title page of manuscript $5(P C 1 / 3 / 2 / 5)$ of $B D$, Paton seems to be wishing to break out of this mould, since he writes a note to himself: "Less realism?" 
The tension between Jenkinson and his wife Alice has been caused partly by his generosity to various needy families, of which she has disapproved, but largely by their inability to conceive children. On the same night that he and Ruth have made love Alice finally discovers that she is pregnant, and announces this to her husband. The reconciliation between the spouses, expressed in light conversation about the long-awaited child (ST, p. 248-249), occurs instantly, though Jenkinson hides his grim feelings. When Ruth uses the health of the sisters' elderly father, the General, as an excuse to depart immediately, Jenkinson drives her down to him. On Jenkinson's return before lunch, his heart is not as heavy as it had been: "Ruth Carrington was to be forgotten; they [he and Ruth] had both decided that" (ST, p. 249). The sudden about-turns on all sides are exceptionally unconvincing and the impression created is that, having engineered the situation, Paton wants to escape from it as quickly as possible.

Paton's ambivalence is further evident when, having established the real love between Ruth and Jenkinson, he dismisses it quickly once Alice falls pregnant, only to recall it when Ruth is married some time later. Paton describes Jenkinson's mixed feelings at her wedding and replaces his initial choice of a noun to convey Jenkinson's main response, "sadness", by the more evocative "renunciation" in the manuscript (ST, p. 280). Perhaps Paton is attempting to reinforce the complexity of Jenkinson's character: almost saintly in selflessness, endeavouring to act in a Christian manner, yet ultimately bitter and jealous.

Not only here, but in BD as well, Paton moves away rapidly from descriptions of deep feelings. For instance, after Dr. Macnab's death, the second book once again evidences Paton fleeing from the intensity of the particular, opening with a panoramic sweep, offering a communal viewpoint, around the Atherton churchyard and the memories it contains (BD, p. 237). The ending of BD, where Cromwell stares into the mists at the time of Jarvis's death, evidences a similar tendency on the part of the author.

\section{Political tensions: gentlemen, conservatives and radicals}

A number of other intriguing issues emerge from dialogues between Trollip and Westacres. At the tennis party Trollip complains: "What d'you bring me here for, fifty-six \& doddering, to see all these youngsters rollicking about? It's a damn fine sight ... but it upsets 
me. Phaugh!" The issue for the doctor is clearly not primarily his age, however, he adds, "Remind me that we are men of property, ${ }^{15}$ \& haven't lived for nothing" (ST, p. 73). Trollip's tirade to Westacres is worth quoting in some detail. He initially seems to be stating a relatively liberal view, critical of Westacres's investment in conservative values. But he immediately adds,

Deasland's educated niggers will infest this countryside before then. ... Why the devil didn't Deasland ... take up schoolmastering or politics or something? He'd have been a great figure by now. (ST, p. 73-74.)

Westacres's reaction is to comment ("evenly", which hints at controlled emotion), "Deasland's a gentleman" (ST, p. 74). Trollip answers,

He's not a gentleman. He's a saint. No gentleman would do his job. His job cuts at the very roots of the system which produces gentlemen. He's a damned Radical, \& a Radical saint is the most dangerous man alive. They ought to be killed young. (ST, p. 74.)

Several matters surface from this fascinating dialogue. For instance, the inferred author appears to concur both with Trollip's query as to the purpose of existence and his impatience with Westacres's unquestioning acceptance of the status quo. Paton does not offer an outright critique of Trollip's overt racism, though certainly Trollip's words cause Westacres to feel discomfort, which he expresses in his defence of Deasland as a "gentleman". But his argument is sharply dismissed by Trollip, who, not in jest, declares Deasland to be a dangerous Radical.

The designation "gentleman", used often in this novel, has a particular, distinctly English, resonance, as will have become clear. One may very instructively compare the doctor's appellation of Deasland as a "Radical" with the authentic contemporary case recorded by Morrell (2001:258): that of Ralph Tatham, a member of a powerful Midlands family, who became increasingly involved in Radical politics. In the words of an indubitable member of the establishment, a senior police officer, he became "Anti-British" and professed to be "a revolutionist and a republican". The police officer damningly thought ship of property is, in all four of Paton's early novels, a normative marker of true identity. 
Tatham an "inconsequential and shallow man" and "not altogether of sound mind" (Morrell, 2001:266n11, quoting a letter by the Deputy Commissioner of the CID, Transvaal, to his counterpart in the South African Police, Transvaal, 25 April 1918).

Such prejudiced criticism is not levelled at Deasland by Trollip, but it is specifically recorded that other members of the community were enraged with Deasland over his efforts. This view is not shared by the narrator, who implies that Deasland's labours are wholly laudable. The fact that Westacres quickly changes the subject suggests that he finds Trollip's criticism of Deasland, though not his racism, disturbing. The kind of identity imparted to Westacres by the narrator, it would seem, is one which approves of idealism, is not interested in politics and is insensitive to racism. One may infer that the author does not concur with Westacres, but also that he does not acquiesce in Trollip's views either.

In a later episode, the doctor mocks Westacres: "You're still a Conservative" (ST, p. 233) and explains his use of this word at length, in much the same terms he has used previously. He informs his host that though the latter believes in a landed aristocracy,

... such a thing can never be in this of all countries. Deasland is seeing to that. He's more honest, at least; he sees that these niggers must absorb or be absorbed by our society, \& he's accelerating the process. But it means the end of these youngsters of ours. It seems damnable ... [b]ut that wasn't my point. It's the growing up of these youngsters that saddens me. (ST, p. 224.)

Westacres responds that he does not see much point in the doctor's "lamentation" (ST, p. 224-225). While this passage is repetitive it does emphasise the inevitable and unwelcome passage of time. Social change is admitted to constitute part of this process, but is also not welcome, preferably to be delayed. Society is indeed perceived as conservative in the doctor's sense, holding onto its white identity as long as possible, its racism blatantly expressed by one of its leading members, its attitudes not interrogated by the author.

Dr. Trollip is deeply unsettled by his thoughts, as is demonstrated by his irrational anger with his son Victor, who briefly plays the fool (ST, p. 226). The narrator appears distant from the scene, and particularly from the Trollips, so that while no overt opinion about them is ex- 
pressed 16 it is made clear that the narrator does not associate himself with them or their responses: of disquiet at changing circumstances on the doctor's part and of immaturity on the part of his son. It is worth noting that father and son are central to their respective age groups in the white community and may be taken as expressing its own sense of a threatened identity.

\section{A racialised religious environment}

In only one sequence is the black populace (as a community) accorded a doubtful, again stereotypical, identity, where Jenkinson and Michael set out for a proposed visit to St Luke's (ST, p. 81). As they enter the location its bare countryside and yawning dongas are emphasised, in contrast to the "green rolling country" of the whiteowned farms. Jenkinson observes, "Overstocking, ... Deasland's fighting a losing battle over that. These people won't give up their stock; it's money to them" (ST, p. 81). The social and economic gap between the black and white farmers is embodied in the distant gaze which Jenkinson brings to bear here $\mathbf{1 7}$ and his construction of the former as others: others for whom, moreover, he for once clearly does not feel responsible.

Jenkinson responds, again in remote and Eurocentric vein, though it is evident that the author intends him to suggest a holistic and fruitful mission at St Luke's,

Wait till you see what they do here. It's not all school \& church, like some people think. You get Deasland talking ... These people have learnt to plough deep, \& sow properly, ... Wait till you meet some of these old native ministers. Really good fellows, they are. (ST, p. 83-84.)

Deasland comes out to meet them from the house "under the shadow of the imposing church that dominated the square of the settlement" (ST, p. 84). While this description is also undoubtedly meant to connote the beneficent presence of Christianity, to a 21st century reader it is tonally most ambiguous, as is the indication that many black babies are named after Deasland, presumably as a paternalistic benefactor. Deasland makes the frivolous remark that p. 257), which one may take as representing the inferred author's view.

17 It evidences a blithe unawareness of the environmental consequences of the colonialist incursion (Ashcroft et al., 2006:491). 
other names than his own are coming into fashion: he is going to baptise an infant who is to be called Barry Crane Gumede, "[b]ut his mother calls it "Bally Clane'" (ST, p. 85). There is no indication that the narrator is conscious of any tension stemming from Deasland's mockery of his congregant's English pronunciation here.

As the party nears the church the more detailed depiction of the building and of the people praying there is also distinctly ambivalent in its effect. The intention is clearly to portray an edifice which is both impressive and natural. It is a lofty building of brick, unplastered, giving it "a look of coolness \& peace" (ST, p. 86). Yet the sense of transcendent serenity being aimed at by the narrator is entirely undermined by Michael's thoughts. He, "with the picture of the raw, blanketed pagans of the location in his mind", wonders "what might be passing in those primitive minds, what prayers were spoken from those primitive hearts" (ST, p. 86-87). That these debasing ideas (cf. Spurr, 1993:77) are not simply those of Michael himself, nor even only of the Midlands community, and are not questioned by the narrator, is evident in Deasland's next words: "We believe in prayer ... . To slip in here ... helps many of these people. It keeps them in touch with a reality that is otherwise utterly remote from their tradition." Michael, "under the sway of this quiet man, did not question it" (ST, p. 87). There is no suggestion that the reader should doubt Deasland's authority or his dismissive othering of the traditions of "these people" either.

Deasland's lengthy response (ST, p. 88-89) is thought-provoking, for though it reflects the understandable need of the mission to market its products, it also mirrors the ingrained paternalism of the time. Spoken as it is by a figure who embodies a manly Christianity, it clearly reflects Paton's own construction of and identification with the identity of such a person. Relationship with the black others is for the sake of "civilising" them rather than for their own sake.

\section{Deasland remarks that:}

Until these people finally change over to a new way of life, keeping good stock \& less of it, ... there will be very few openings for our products ... Of course your [Jenkinson's] people ... think we are causing the change, ... but that's only half the truth. We are convinced the change must come, an inevitable result of a backward population adjacent to a progressive one. (ST, p. 88.)

To this speech Jenkinson merely observes, "You're sure of it" (ST, p. 88). Deasland's eyes "smoulder", to Michael's surprise at his in- 
tensity, and he launches into the second half of his monologue, which one may interpret as normative for Paton also.

Deasland declares,

I believe in the uplifting force of Christianity among these people, Jenks. But not only in the dim light of a church. Out here, man, in the fields \& on the hills. ... We want them to be able to build \& carpenter \& plough, ... Education is the helping of the native to share your culture \& your tradition \& to understand \& venerate your laws; leave him alone, with his blankets \& his sunshine, \& he becomes a drag on your advancement \& a menace to your prosperity. (ST, p. 89.)

As already suggested, the only response to this questionable utterance in the text $\mathbf{1 8}$ is presented partly through Michael, who at this stage sees himself as a future doctor at St Luke's. There is certainly an ironic stance towards the "glow of righteousness" which Michael feels as he imagines "little Michael Gumedes" running about "while their guardian \& benefactor wore out body \& soul in the service of them" and towards his fantasy that "it would be a great thing to be a man like Deasland - ... a great man like Deasland, only greater" (p. 89). Michael's construction of Deasland as "great" is not apparently questioned and is indeed emphasised by the text as a whole. In BD Paton makes no attempt to broach such issues of racial upliftment, confining himself almost entirely to the internal dynamics within the white community, and the same is true of the other early works. Religious good works are confined to the white sector of the population, and though some characters dissent from Christianity, on the whole its discourse is unquestioningly naturalised and valorised.

\section{Conclusion}

It seems obvious that Paton was already practising that ability to write which makes Cry, the beloved country so powerful as a tool of protest though, in some respects, the later text does not delve as deeply into the problematics of individual identity as some of his earliest works. The main character there is not so much the separate individuals, not even James Jarvis and Stephen Kumalo, as the

18 The sentiments are disturbingly like those in the 1929 poem "No responsibility accepted", where it is suggested that both whites and blacks may end up lying in the sun, watching their toes lift one by one (Paton, 1995:140). I am not convinced that this poem is purely satirical. 
beloved country itself, so that it is the identity of a fractured nation which is being examined. Hence, I suggest that the tentative explorations of the complexity of human identity in the early fiction reach fruition, rather, in Too late the phalarope, where social, theological and psychological issues such as interracial relationships, the deadly effects of apartheid, sexuality, guilt and a lack of forgiveness are considered in some depth through the medium of a credible plot and more fully-delineated characters than in Paton's other fiction.

\section{List of references 19}

ABBOTT, H. 2002. The Cambridge introduction to narrative. Cambridge: Cambridge University Press.

ALEXANDER, P. 1994. Alan Paton: a biography. Oxford: Oxford University Press.

ASHCROFT, B., GRIFFITHS, G. \& TIFFIN, H. 2006. Introduction to part 18: environment. (In Ashcroft, B. Griffiths, G. \& Tiffin, H., eds. The postcolonial studies reader. 2nd ed. London: Routledge. p. 491-493.)

BRASS, P. 2001. Housman's England: empire had its privileges. Gay and lesbian review worldwide, 8(5):49.

COETZEE, J.M. 1988. White writing: on the culture of letters in South Africa. New Haven: Yale University Press.

CORNWELL, G. 1992. The early South African novel of race. (In Chapman, M., Gardner, C. \& Mphahlele, E., eds. Perspectives on South African English literature. Parklands: Ad Donker. p. 75-93.)

DAVENPORT, T. \& SAUNDERS, C. 2004. South Africa: a modern history. 5th ed. Basingstoke: Macmillan: St. Martins Press.

DE KOCK, L. 1996. The pursuit of smaller stories: reconsidering the limits of literary history in South Africa. (In Smit, J. et al., eds. Rethinking South African literary history. Durban: Y Press. p. 85-92.)

DE KOCK, L. 2001. South Africa in the global imaginary: an introduction. Poetics today, 22(2):263-298.

DE KOCK, L. 2004. South Africa in the global imaginary: an introduction. (In De Kock, L., Bethlehem, L. \& Laden, Sonja, eds. South Africa in the global imaginary. Pretoria: Unisa Press. p. 1-31.) (Reprinted, slightly altered.)

ELPHICK, R. 1997. The benevolent empire and the social gospel: missionaries and South African Christians in the age of segregation. (In Elphick, R. \& Davenport, R., eds. Christianity in South Africa: a political, social and cultural history. Oxford: Currey. p. 347-369.)

FOLEY, A. 1998. Considered as a social record: a reassessment of Cry, the beloved country. English in Africa, 25(2):63-92.

19 PC denotes an item in the Alan Paton Collection and Struggle Archives, University of KwaZulu-Natal, Pietermaritzburg. Other manuscripts consulted, with different methods of cataloguing, are to be found in the Manuscripts Collection (which includes the Hofmeyr Collection), William Cullen Library, University of the Witwatersrand, Johannesburg. 
FOLEY, A. 2005. The principle of the principal as principal: narratorial identity and perspective in Alan Paton's Diepkloof stories. Current writing, 17(1):70-89.

GALSWORTHY, J., 1976 [1906]. The man of property. (First part of The Forsyte saga.) London: Heinemann. (Six-volume omnibus of The Forsyte saga and $A$ modern comedy.)

HOUSMAN SOCIETY. 2007. http://www.housman-society.co.uk/ Date of access: 14 Jan. 2007.

LAMBERT, J. 2006. "An unknown people": writing a biography of white Englishspeaking South Africans. Inaugural lecture. 2 Nov. Pretoria: Unisa.

LEVEY, D. 2007. Identity in the early fiction of Alan Paton, 1922-1935. Potchefstroom: North-West University. (Unpublished Ph.D. thesis.)

MANGAN, J. 1981. Athleticism in the Victorian and Edwardian public school: the emergence and consolidation of an educational ideology. Cambridge: Cambridge University Press.

MANGAN, J. 1990. Making imperial mentalities: socialisation and British imperialism. New York: Manchester University Press.

MARTINEZ LIROLA, M. 2006. Personal communication. Pretoria.

MORRELL, R. 2001. From boys to gentlemen: settler masculinity in colonial Natal, 1880-1920. Pretoria: Unisa Press.

PATON, A. 1922-1923. Ship of truth. Unpublished manuscript, Alan Paton Collection: Book 1: PC1/3/1/1; [Book 2 missing]; Book 3: PC1/3/1/2.

PATON, A. 1923. Unpublished letter to R. Pearse, 22 April (photocopy). PC64/1/1/7.

PATON, A. 1928? Little Barbee. Unpublished manuscript. PC1/3/4/9. (Dated thus in pen by Paton; the manuscript itself is in pencil.)

PATON, A. 1930a. Brother death. Unpublished manuscript, Alan Paton Collection: MS 1: PC1/3/2/1; MS 2: PC1/3/2/2; MS 3: PC1/3/2/3; MS 4: $\mathrm{PC} 1 / 3 / 2 / 4 ; \mathrm{MS}$ 5: PC1/3/2/5.

PATON, A. 1930b. Calvin Doone. Unpublished short story in MS 5 of Brother death. $\mathrm{PC} 1 / 3 / 2 / 5$.

PATON, A. 1932-1933. Louis Botha. Unpublished play in several versions: $\mathrm{PC} 1 / 3 / 3 / 1-4$. Another typescript version is to be found in the Hofmeyr Collection, William Cullen Library. Johannesburg: University of the Witwatersrand. A1/L01.

PATON, A. 1934a. God in modern thought. Unpublished typescript. PC1/1/17/8.

PATON, A. 1934b. John Henry Dane. Unpublished manuscript. PC1/3/4/1.

PATON, A. 1934c. 20 Religion, freedom and man. Unpublished and unfinished essay. PC1/3/5/4.

PATON, A. 1934d. Secret for seven. Unpublished manuscript. PC1/3/4/6.

PATON, A. 1948. Cry, the beloved country. London: Jonathan Cape.

PATON, A. 1951. Letter to SG Millin. 23 September. Manuscripts Collection, William Cullen Library. Johannesburg: University of the Witwatersrand. A $539 / \mathrm{C} 2$.

PATON, A. 1953. Too late the phalarope. New York: Scribner.

20 I argue that this is the same as the supposedly lost MS Religion and my generation (Alexander, 1994:115). In places the argument repeats that in Paton (1934a). 
PATON, A. 1980. Towards the mountain: an autobiography. Cape Town: David Philip.

PATON, A. 1981. Ah, but your land is beautiful. Cape Town: David Philip.

PATON, A. 1988. Journey continued: an autobiography. Cape Town: David Philip. Ed. by P. Kohler. Durban: Gecko Books.

PATON, A. 1995. Songs of Africa. Ed. by P. Kohler. Durban: Gecko Books.

RIMMON-KENAN, S. 2002. Narrative fiction: contemporary poetics. 2nd ed. London: Routledge.

SPURR, D. 1993. The rhetoric of empire: colonial discourse in journalism, travel writing, and imperial administration. Durham: Duke University Press.

THOMPSON, P. 1999. The British civic culture of Natal South Africa 1902-1961. Howick: Brevitas.

VAN DER VEER, P. 2006. Global conversions. (In Ashcroft, B., Griffiths, G. \& Tiffin, H., eds. The post-colonial studies reader. 2nd ed. London: Routledge. p. 534-536.)

VAN WYK SMITH, M. 2001. From "boereplaas" to Vlakplaas: the farm from Thomas Pringle to J.M. Coetzee. (In Van der Merwe, C., ed. Strangely familiar: South African narratives in town and countryside. s.l.: Content Solutions. p. 17-36.)

WITTENBERG, H. 2004. The sublime, imperialism and the African landscape. Cape Town: University of the Western Cape. (Unpublished D.Litt. thesis.)

WITTENBERG, H. 2005. Alan Paton's sublime: race, landscape and the transcendence of the liberal imagination. Current writing, 17(1):3-23.

\section{Key concepts:}

Alan Paton
identity
manuscripts
politics
religion
South African literature in English
unpublished fiction

Kernbegrippe:

Alan Paton

godsdiens

identiteit

manuskripte

ongepubliseerde fiksie

politiek

Suid-Afrikaanse letterkunde in Engels 